\title{
OPTEGNELSER AF MINA GRUNDTVIG DEN 4. AUGUST 1856
}

efter Erindringen fra en Samtale med N.F.S. Grundtvig en Maanedstid tilbage, dog stottet med korte Notitser straks efter Samtalen.

\begin{abstract}
(Skænket til Grundtvig-Selskabet af Grundtvigs sønnesøn fhv. overbibliotekar Vilhelm Grundtvig og udgivet med oplysninger af cand. mag. Steen Johansen).
\end{abstract}

Efter at være bleven Candidat prædikede G. til Dimiss ${ }^{1}$ ), og søgte derpaa om at blive personel Cappelan hos sin Fader, men dette blev negtet ham, og af den Grund søgte hans Fader snart efter sin Afsked ${ }^{2}$ ). Nogle Aar senere udvirkede Biskop Balle, som bestandig var G.s Ven, at han blev pers. Cappelan og hans Fader igjen indsat i sit forrige Embede $\left.{ }^{3}\right)$. Efter sin Faders Død kom han ind til Kiøbenhavn og prædikede i de fleste Kirker og i Capellet hos Dronning Marie Sophie Frederikke ${ }^{4}$ ). I denne Tid blev han opfordret til at søge et lille Præstekald i Aalborg, som han egentlig ingen Lyst havde til, men syntes dog da Opfordringen kom - efter hvad man skulde troe - directe fra Kongen, at han ikke burde undslaae sig fra at søge det. Da Dagen som skulle bringe Afgjørelsen for dette Embedes Besættelse kom, blev G. buden til en Embedsmand i Kiøbenhavn, hvis Broder var en formaaende Kiøbmand i Aalborg, og som havde skrevet, at Stemningen der var for ham, og at det var utvivlsomt, at G. maatte faae Embedet. Middagsselskabet var bestemt til den Tid, da man kunde vente Afgjørelsen, og en Embedsmand havde lovet at indfinde sig for at Grundtvigs Skaal kunne blive drukket; da Middagsmaaltidet nærmede sig sin Ende, og endnu Manden fra Canceliet ei var kommen, forstod man at G. ei havde faaet Embedet, og Dagen efter læstes ogsaa i Aviserne at en anden var udnævnt ${ }^{5}$ ). Men han blev fremdeles ved at prædike rundt om i alle Byens Kirker og blev derpaa et halvt Aar efter kaldet af Fredrik 6 til Præstø uden derom at have indgivet Ansøgning ${ }^{6}$ ). Han havde Audients hos Kongen, takkede ham for hans Naade og bad at hans 
Maj. vilde gunstigst erindre ham, naar der blev et Embede i K[bh.] ledigt. Efter at have været et Aar i Præstø søgte han Frelsers Embede paa Christianshavn og fik det ogsaa ${ }^{7}$ ). Kort efter at han havde tiltraadt det, begyndte Striden med Clausen, og efter at have været der i 4 Aar tog han sin Afsked og fik den uden Pension, som han da heller ikke havde søgt $\mathrm{om}^{8}$ ).

Han beskæftigede sig nu med Verdenshistorie og oppebar i Honorar som Historieskriver af Kongen $600 \mathrm{Rbd}$., som han ei vidste om han beholdt efter at have taget Afsked, men da Pengene paa sædvanlig Tid bleve ham tildeelte, forlangte han Audients for at takke Kongen. Kongen var meget barsk og sagde, det var forfærdeligt han heller aldrig kunne holde Fred med de andre Præster. G. svarede „men er Deres Maj. ogsaa vis paa, det er mig der ikke kan holde Fred“. Kongen betænkte sig et Øieblik og svarede derpaa „nei, nei det er ogsaa sandt“, hvorpaa han gik over til at tale med ham om hvad han beskiæftigede sig med nu, hvortil G. svarede ,aa, saagodtsom ingenting“. Kongen spurgte da hvad han havde Lyst til og hvad han kunde giøre for ham, G. sagde „Deres $M$. kunde lade mig reise til England og studere Angelsachsisk“. Kongen sagde, at dette Ønske skulde blive opfyldt, og en Tid efter reiste han ${ }^{9}$ ).

Da han kom tilbage fra England, følte han en uimodstaaelig Trang til igjen at prædike og forlangte Audients hos Steman, Cancellipræsident, for at bede ham udvirke Tilladelse til, at han maatte prædike $\mathrm{i}$ en af Byens Kirker. Steman nægtede det i meget haarde Udtryk og sagde, at han kunde jo vedblevet at tale, da han havde Lov, nu maatte han tie; G. svarede, at det var nettop det, han ikke længere ville, han ville tale, og da han blev negtet Tilladelse at prædike i en af Kirkerne, vilde han fra nu af fremme de gudelige Forsamlinger og selv sætte sig i Spidsen for en saadan Forsamling ${ }^{10}$ ). Søndagen efter denne Samtale prædikede [han] paa Rolighed ${ }^{11}$ ) og indrettede paa Christianshavn paa en Pakbod en Forsamlingssal, som skulde tages i Brug saa snart som muligt; imidlertid blev han indstævnet for Politiet, som vilde han skulde undertegne og vedgaae, at han fandt sig i Forbudet imod hans Optræden i gudelige Forsamlinger, men da han fremdeles ei heller ved Biskop Møllers Indflydelse kunne skaffes Adgang til at prædike i nogen Kirke, protesterede han i Protokollen imod Forbudet. Søndagen derpaa var bestemt til den første Forsamling paa Christianshavn. Om Løverdags Aftenen stimlede en Mængde Mennesker sammen omkring G.s Bolig (see Bladene fra den Tid), og man havde fortalt ham, at Vinduerne ville blive slaaede ind. Han fæstede ei noget videre Tro til denne Trudsel, men hans Kone var dog saa bange, da hun saa alle Menneskene, at hun flyttede Sengen med deres yngste Barn saa langt 
fra Vinduet som muligt. Seent Fredag Aften havde G. imidlertid faaet Tilladelse til at prædike til Aftensang i Fredriks Kirke paa Christianshavn, og det til Forsamlinger indrettede Locale blev derfor aldrig benyttet, da han Søndagen derpaa begyndte sine Aftensangsprædikener i F. K., som han siden stadig i 7 Aar hver Søndag holdt ${ }^{12}$ ).

Da det leed henimod den Tid, at han ønskede, at hans Sønner skulde confirmeres ${ }^{13}$ ), blev det ham altid tungere og tungere at tænke paa, at han ei selv havde Lov til at forberede dem til Confirmation, for med Tilladelsen til at prædike i Fredriks Kirke fulgte nemlig et udtrykkeligt Forbud imod at døbe og confirmere. Han forlangte Audients hos Chr. $8^{14}$ ) og spurgte, om hans Maj. vilde nægte ham at confirmere sine Sønner og for Eftertiden alle sine Venners Børn. Kongen lovede, at hvis Stiftets Biskop vilde anbefale denne Sag, skulde hans Sanction ikke mangle ${ }^{15}$ ). Nytaarsaften gik da G. til Mynster, som modtog ham koldt og paa hans Spørgsmaal om at der maatte gives ham Tilladelse til at confirmere sine Sønner, svarede kort og godt nei. G. sagde, at han maatte dog betænke, at han var ordineret Præst og Cappelan, hvortil Mynster svarede, ,troer De da vi kunne give enhver forfløien Cappelan Lov til at confirmere?" Grundtvig svarede, „ja, naar jeg staar for Deres Høiærv. som en forfløien Cappelan, saa har jeg ei meer at sige". Han gik meget nedslaaet derfra, og da han gik hjem tilbage gjennem Kongens Have i den stierneklare Nytaarsaften, tænkte han rigtig over, hvor underlig smerteligt det var, at en Fader ei skulde kunne have Lov til at gjøre alt hvad han følte Trang til for sine Børn ${ }^{16}$ ).

En kort Tid efter, da han nettop havde bestemt at hen sende sine Sønner til Busck, blev han opfordret directe fra Kongen om at søge Vartou. Han fik Audients og sagde, at han havde tænkt at søge Vartou, hvis han kunde være vis paa at faae det. Kongen svarede, han gav aldrig saadanne Løfter. Grundtvig sagde, „da indgiver jeg heller ingen Ansøgning“. Kongen endte dog med at sige „skriv Deres Ansøgning G. og send mig den". G. gik lige hjem og skrev den og bragte den selv tilbage til Kongen, som kort efter udnævnte ham til Præst ved $\operatorname{Vartou}^{17}$ ).

\section{O PLYSN IN GER ${ }^{1}$ )}

Indledning. Mina (Vilhelmine) Grundtvig var datter af den norske teo$\log$ professor St. J. Stenersen, ungdomsven af N. F. S. Grundtvig. Hun var født i 1828 og blev i okt. 1855 gift med Gr.s ældste søn Johan Grundtvig (1822-

1) Forkortelser i det følgende: Breve = Breve fra og til Grundtvig I-II, 1924-26. Rønning = F. Rønning: N. F. S. Grundtvig I-IV, 1907-13; hvert bd. er delt i 2 halvbind (I,1, I,2 o.s.v.). 
1907), officer i Treaarskrigen, senere historiker og arkivmand. At Johan valgte at tage en datter af sin faders afdøde norske ven til hustru synes at have glædet Gr. meget, jvf. brevene nr. 629 og 634 i Breve. - Som angivet fandt fru Minas samtale sted i juli 1856. Gr. var dengang enkemand for anden gang; fra flere kilder ved vi, at han netop da befandt sig $i$ en periode af træthed og mismod, han var kommet til at se meget gammel ud, og baade han selv og hans nærmeste mente, at hans tid snart var omme. Maaske er disse omstændigheder grunden til, at hans svigerdatter har udspurgt ham om hans levnedsløb. I teksten er tegnsætningen blevet normaliseret, men ortografien er Mina Grundtvigs. En form som „nettop“ (med 2 t'er) er uden tvivl en norskhed.

Note r. 1. Gr. blev teologisk kandidat i okt. 1803, men først i 1810 tænkte han paa at søge præstekald. Sin dimisprædiken holdt han i marts 1810. Rent bortset fra, at Gr. i sine kandidataar snarere drømte om en løbebane som forfatter, eventuelt som professor ved universitetet, end som præst, var det dengang almindeligt, at teologiske kandidater matte vente ofte $i$ mange aar paa at faa embede. - 2. I marts 1810 ansøgte Gr.s fader om at maatte faa sin søn som medhjælper i sin gerning, et skridt, som faderen foretog med sønnens noget forbeholdne billigelse. Ansøgningen blev ikke efterkommet. I efteraaret 1810 gennemgik Gr. den bekendte religiøse krise, ledsaget af sygdomsanfald. Ved juletid tog han hjem til Udby, hvor hans gamle fader i mellemtiden havde søgt og faaet sin afsked pr. ${ }^{1} / 1$ 1811. Efter krisen følte Gr. for alvor kaldet til at være præst, og i Udby blev det aftalt, at Gr.s fader skulde søge sit embede igen, medens Gr. skulde søge om at blive hans kapellan. - 3. Ikke nogle aar senere, men et halvt aar efter blev Gr. kapellan i Udby (juni 1811); i april samme aar havde hans fader faaet sit embede igen. - 4. I Udby var Gr. personelkapellan, d.v.s at han var knyttet personligt til sognepræsten, saa længe denne levede, men ikke længere. Følgelig mistede Gr. sin stilling, da hans fader døde $\mathrm{i}$ jan. 1813. Han søgte om at blive faderens efterfølger som sognepræst i Udby, men uden held, og i aug. 1813 bosatte han sig i København. Her ( $\mathrm{og}$ paa Frederiksberg) prædikede han indtil slutn. af $1815 \mathrm{i}$ enkelte kirker, hvis præster var villige til at overlade ham prædikestolen. I 1816-20 prædikede han saa godt som ikke (og slet ikke i Kbh.). Først efter at han $2 / 2$ I821 var blevet udnævnt til præst i Præstø, fik han i den sidste ca. halvanden maaned, før han tiltraadte dette embede, tilbud om at prædike i flere kirker, og bl. a. ogsaa en enkelt gang for hoffet (Rønning II,2, 194). - 5. Vedrørende det ledige kapellani i Aalborg (i sept. 1818), som Gr. (kun nødigt) søgte, se hans fremstilling i Kirke-Speil 1871, s. 380, hvor den samme episode skildres, jvf. ogsaa brev nr. 193 i Breve. - 6. Baade tidsangivelsen „et halvt Aar efter“ og ordene „han blev fremdeles ved at prædike (o.s.v.) “, maa bero paa en misforstaaelse, dersom de knyttes til ansøgningen om embedet i Aalborg i sept. 1818, jvf. note 5. Men maaske er der her sket en forveksling med tiden for Gr.s (tredie) ansøgning om embedet i Citadellet i efteraaret 1820, se brev nr. 225 i Breve samt Rønning II,2, 192. - 7. ${ }^{6} / 111822$ udnævntes Gr. til residerende kapellan ved Vor Frelsers kirke paa Christianshavn. - 8. Striden med 
prof. dr. theol. H. N. Clausen indledtes med udgivelsen af „Kirkens Gienmæle“ i sept. 1825. I maj 1826 søgte og fik Gr. sin afsked som præst. - 9. I maj 1828 ansøgte $\mathrm{Gr}$. kongen om understøttelse til et aars ophold $\mathrm{i}$ London for at studere haandskrifter (ansøgningen $=$ brev nr. 318 i Breve). Audiensen, hvori Gr. har talt med kongen om dette, har sikkert fundet sted ikke længe før. I Kirke-Speil 1871, s. 388 har Gr. ganske kort skildret samme audiens, hvoraf vi i fru Minas optegnelser faar et noget udførligere referat. Gr. fik dog ingen understøttelse i 1828, men først det følgende aar (efter at han igen i dec. 1828 havde ansøgt derom). Mærkeligt nok fortæller Gr., at han ikke vidste, om han efter embedsnedlæggelsen beholdt honoraret som historieskriver, skønt vi har hans i 1828 affattede ansøgning (=nr. 324 i Breve), hvori han ikke synes at røbe nogen uvidenhed. - 10. Audiensen hos P.C. Stemann fandt sted $11 / 2$ 1832; referat (efter Gr.s nedskrift) i Rønning II1,2, 59-61. - 11. „Lille Rolighed" var navnet paa J. Chr. Lindbergs bolig ved kalkbrænderiet uden for Østerport, hvor han (Lindb.) i en kortere periode holdt gudelige forsamlinger (de saakaldte „Kalkbrænderiforsamlinger"). - 12. Fru Minas oplysninger om, hvad der foregik $\mathrm{i}$ ugen ${ }^{26} / \mathrm{L}_{2}-{ }^{4} / 31832$ supplerer paa en interessant maade den viden, man ellers har om disse begivenheder (Kirke-Speil 1871, s. 390391 , brev til Gunni Busck ${ }^{28} / 2$ 32, Chr. S. Leys dagbogsoptegnelser i Jungersen, Nygård og Schrøder's tidsskrift Danskeren VII 1892, s. 48-51), hvortil henvises. Biskop P.E. Müller var ganske vist til at begynde med meget utilbøjelig til at føje Lindberg ( $\mathrm{og}$ Gr.) $\mathrm{i}$ deres ønske om at fortsætte forsamlingerne, men det var dog ham, som hurtigt udvirkede, at Gr. blev aftensangsprædikant i Frederikskirken paa Christianshavn, hvor han søndag $4 / 3$ holdt sin tiltrædelsesprædiken. Gr.s protest i politiprotokollen er forgæves eftersøgt i Københavns Politis Arkiv i Landsarkivet (meddelt af Vilh. Grundtvig). Angaaende det lejede lokale (som aldrig blev taget $\mathrm{i}$ brug), se nr. $357 \mathrm{i}$ Breve. Nyt for os er det at erfare om det store opløb foran Gr.s bolig (Strandgade nr. 4, tæt ved kirken) lørdag aften den 3. marts. I bladene fra den tid er - trods eftersøgning baade af Vilh. Grundtvig og af disse noters forf. - intet fundet om denne sammenstimlen. Om forløbet af Gr.s første gudstjeneste i Frederikskirken se Rønning III,2, 63 f. - 13. Johan Gr. var født 1822, Svend Gr. 1824. Spørgsmaalet om deres konfirmation blev for Gr. aktuelt i efteraaret 1838 . - 14. Fejl for: Frederik VI. Audiensen fandt sted ${ }^{17} / 12$ 1838, jfr. Gr.s brev til Gunni Busck ${ }^{18} /{ }_{12}$ (H. Bech: Gunni Busck, 2. udg. 1878, s. 212), der bekræfter og supplerer nærværende skildring. - 15. Det var ikke kongen, men kancellipræsident Stemann, som overfor Gr. ytrede, at konfirmationstilladelsen afhang af biskoppens anbefaling, jvf. Gr.s brev til Busck ${ }^{22} /{ }_{12} 38$. - 16. Om sit besøg hos biskop Mynster fortæller Gr. i „Kirke-Speil“ 1871 blot dette (s. 392), at „(jeg fandt) ham ikke blot saa ubøielig, men saa bitter og fiendtlig, at jeg efter en timelang Samtale i Sophaen maatte gaae bort med en haanlig Afviisning og, jeg nægter det ikke, i en oprørt Stemning, som jeg frit gav Luft.“ Det (hidtil ukendte) replikskifte, vi lærer at kende af fru Minas optegnelser, er maaske selve denne haanlige afvisning til slut. Hvorledes iøvrigt den timelange samtale (som Gr. i et brev til Busck kalder „lang og uforglemmelig") har formet sig $i$ enkeltheder, derom er vi desværre uvidende. N. M. Plum mener ( $i$ 
Gads danske Magasin 1939, s. 378), at man udfra Gr.s ord om den oprørske stemning, som han frit gav luft, tør slutte, at Gr. sikkert har givet Mynster det glatte lag. Ikke omtalt i de her meddelte optegnelser er, at Gr. paa hjemvejen fra bispen fik hele sit haab og mod tilbage ved synet af de kvidrende spurve $i$ Kongens Have. Sit stemningsomslag udtrykte han i det skønne digt NyaarsAften, som han offentliggjorde faa dage efter i Dansk Kirketidende ${ }^{6} / 11839$, jvf. Gr.s Poetiske Skrifter VI, 204-206. - 17. Smlgn. Kirke-Speil 1871, s. 393-394, brev til Busck ${ }^{26} / 3$ 1839, Rønning III,2, $221 \mathrm{ff}$. 